\title{
Performance evaluation and modeling of the activated sludge system used in Riqqa, Kuwait
}

\author{
A. Abusam, H. Al-Naser \& A. Shahalam \\ Water Resource Division, Water Technologies Department, \\ Kuwait Institute for Scientific Research, Kuwait
}

\begin{abstract}
The wastewater treatment plant (WWTP) located in Riqqa, Kuwait, has shown signs of instability. The chemical oxygen demand (COD) in the secondary effluent COD was found to be particularly unstable (fluctuating sharply between 30 and $200 \mathrm{mg} / \mathrm{l})$. This paper presents the performance evaluation conducted by the Kuwait Institute for Scientific Research (KISR) of the activated sludge system, at Riqqa plant. Probable causes are indentified, and a mathematical model is developed. In addition to the system performance records for 20042007, the results of a sampling campaign conducted from March 2009 to March 2010 were also used in the evaluation of the activated sludge system, based on influent and effluent qualities and common operating variables, e.g., hydraulic retention time $(H R T)$, solids retention time (SRT), volumetric organic load $\left(\mathrm{L}_{\mathrm{v}}\right)$ and food-to-microorganism ratio $(\mathrm{F} / \mathrm{M})$. The system was then modeled in a SIMBA platform, using Activated Sludge Model No. 1 (ASM1). The results obtained results indicated that the quantity and degree of biodegradability, i.e. biological oxygen demand-to-chemical oxygen demand ration (BOD/COD) of the wastewater being treated fluctuated greatly, probably due to the illegal discharge of industrial wastewaters or septage. The system, which is controlled manually, was repeatedly being operated outside optimal ranges. To maintain a high quality of treatment, it is recommended that automatic flow controllers be installed in recirculated activated sludge (RAS) and wasted activated sludge (WAS) streams, and that protective strategies be implemented to prevent the discharge of industrial and other toxic or inhibitory substances into the system. The developed model can be used to control and optimize the performance of the system.
\end{abstract}

Keywords: activated sludge, performance evaluation, operating variables, activated sludge modeling, ASM1. 


\section{Introduction}

The State of Kuwait has a harsh environment that is characterized by low rainfall and high evaporation rates (i.e. $150 \mathrm{~mm} / \mathrm{yr}$ and 4,000 mm/yr, respectively) [1]. Because of its very limited natural freshwater resources (i.e. brackish groundwater), the Kuwait relies almost completely on expensive seawater desalination to meet its escalating demand for freshwater brought about by a fast-growing population coupled with increasing urbanization, industrialization, and agriculture. Therefore, reuse of treated wastewater has become an important alternative, unconventional water source for Kuwait. In fact, the country has recently initiated vigorous measures to promote the reuse of treated municipal wastewater for non-potable applications (e.g., agricultural and landscape irrigation), with the aim of significantly reducing the country's overall demand for freshwater [2]. By 2005, reuse has increased to more than 50\% of the centrally collected and treated municipal wastewater [3].

In Kuwait, municipal wastewater is collected and treated in three main municipal wastewater treatment plants (WWTPs) located in Jahra, Riqqa, and Sulaibiya. The WWTP in Riqqa is the second largest in Kuwait. Recently, there have been signs that this plant is working under unstable conditions. Hamoda et al. [4] found that the quality of the plants secondary and tertiary effluents fluctuated greatly (i.e. coefficient of variation between 35 and 50\%). These findings were confirmed through an analysis of the 2004-2007 performance records of the Riqqa activated sludge system (ASS). The main goals of this study, which was conducted by the Kuwait Institute for Scientific Research (KISR), were (i) to evaluate the performance of the Riqqa ASS in order to identify any operational limiting factors and recommend remedial measures, and (ii) to develop a calibrated version of the existing Activated Sludge Model No. 1 (ASM1) for the Riqqa ASS, to enable the model be used for plant performance predictions

\section{Plant description}

The Riqqa WWTP is located west of the Zahr residential area of Kuwait. It treats mainly domestic wastewater of a medium strength (table 1). The Riqqa WWTP has been in operation since 1982, and has an original design capacity of $85,000 \mathrm{~m}^{3} / \mathrm{d}$. However, since the rehabilitation and upgrading in 1997 , the capacity has increased to the present level of $180,000 \mathrm{~m}^{3} / \mathrm{d}$ [5]. The Riqqa WWTP is an activated sludge plant, which uses no primary clarifiers. The raw wastewater flows directly from the preliminary treatment (mechanically raked bar screens and aerated grit chambers) to the secondary treatment units (12 extended-aeration tanks followed by 10 secondary clarifiers). Then, the clarifier effluent flows on to the tertiary treatment units (coarse sand filtration and chlorination). The tertiary effluents are primarily reused in landscape irrigation. Excess sludge is digested in aerobic digesters and then pumped to drying beds before being taken to a municipal landfill. 


\section{Materials and methods}

\subsection{Historical performance evaluation}

The activated sludge performance records for 2004-2007 (inclusive) were collected, tabulated and analysed. In an attempt to explain the high degree of fluctuation in the secondary effluent, four common activated sludge operating parameters were estimated: volumetric organic load $\left(\mathrm{L}_{\mathrm{V}}\right)$, solids retention time (SRT), food-to-microorganism ratio $(\mathrm{F} / \mathrm{M})$, and hydraulic retention time (HRT), eqns. (1)-(4).

$$
\begin{gathered}
L_{V}=\frac{Q_{\text {in }} \cdot B O D_{5, \text { in }}}{V} \\
S R T \approx \frac{V \cdot T S S_{A T}}{Q_{w} \cdot T S S_{R}} \\
F / M=\frac{Q_{\text {in }} \cdot B O D_{5, \text { in }}}{V \cdot V S S_{A T}} \\
H R T=\frac{V}{Q_{i n}}
\end{gathered}
$$

where:

$\mathrm{BOD}_{5, \text { in }}$ : Influent five days biological oxygen demand $\left(\mathrm{kg} / \mathrm{m}^{3}\right)$

$\mathrm{F} / \mathrm{M}$ : Food to microorganism ratio $\left(\mathrm{kg} \mathrm{BOD}_{5} / \mathrm{kg}\right.$ VSS.d)

HRT : Hydraulic Retention Time (d)

$\mathrm{L}_{\mathrm{V}} \quad$ : Organic load $\left(\mathrm{kg} \mathrm{BOD} / \mathrm{m}^{3}\right.$.d)

$\mathrm{Q}_{\text {in }} \quad$ : Influent wastewater $\left(\mathrm{m}^{3} / \mathrm{d}\right)$

$\mathrm{Q}_{\mathrm{w}} \quad$ : Wasted activated sludge $\left(\mathrm{m}^{3} / \mathrm{d}\right)$

SRT : Solid Retention Time (d)

$\mathrm{TSS}_{\mathrm{AT}}$ : Aeration tank total suspended solids $\left(\mathrm{kg} / \mathrm{m}^{3}\right)$

$\mathrm{TSS}_{\mathrm{R}}$ : Re-circulated flow total suspended solids $\left(\mathrm{kg} / \mathrm{m}^{3}\right)$

$\mathrm{V} \quad$ : Volume $\left(\mathrm{m}^{3}\right)$ and

$\mathrm{VSS}_{\mathrm{AT}}$ : Aeration tank volatile suspended solids $\left(\mathrm{kg} / \mathrm{m}^{3}\right)$.

\subsection{Present performance evaluation}

1-liter wastewater samples were collected twice a week from four locations (influent, aeration tank, clarifier underflow, and secondary effluent) for an entire 
year (March 2009-March 2010). Water temperature, $\mathrm{pH}$ and electrical conductivity were measured on-site using Hatch portable kits. Then the collected wastewater samples were taken immediately to the laboratory for analysis of total chemical oxygen demand $\left(\mathrm{COD}_{\text {tot }}\right)$, soluble chemical oxygen demand $\left(\mathrm{COD}_{\text {sol }}\right)$, five-day biological oxygen demand $\left(\mathrm{BOD}_{5}\right)$, total solids $(\mathrm{TS})$, total suspended solids (TSS), total dissolved solids (TDS), volatile suspended solids (VSS), total phosphorus (TP), total Kjeldahl nitrogen (TKN), organic nitrogen (Org-N), ammonium $\left(\mathrm{NH}_{4}\right)$, nitrite $\left(\mathrm{NO}_{2}\right)$, and nitrate $\left(\mathrm{NO}_{3}\right)$ using the standard methods for examination of water and wastewater of the American Public Health Association [6]. Similarly, the system's operating variables were also calculated using eqns. (1)-(4).

\subsection{Model development, calibration and validation}

A model of Riqqa ASS was built on SIMBA platform. The model consisted of 18 continuously stirred tank reactors (CSTR's) in series, representing the aeration tank, and the secondary clarifier. The biochemical processes taking place in the aeration tank were modeled using ASM1, while those taking place in the secondary clarifier were modeled using the double exponential model developed by Takacs et al. [7]. The number of CSTRs (18) used to adequately model the hydraulics of the aeration tank was obtain from eqn. (5) proposed by Davis [8]:

$$
D=1.01 \cdot v \cdot N_{R}^{0.875}
$$

where:

$D=$ coefficient of dispersion $\left(\mathrm{m}^{2} / \mathrm{s}\right)$

$\boldsymbol{V}=$ Kinematic viscosity $\left(\mathrm{m}^{2} / \mathrm{s}\right)$

$N_{R}=$ Reynolds number $\left(N_{R}=\frac{4 u R}{v}\right)$, unit-less

$U=$ velocity in open channel $(\mathrm{m} / \mathrm{s})$ and

$R=$ hydraulic radius (= area/wetted perimeter) $(\mathrm{m})$.

The data used to calibrate the models were obtained during the period from March to September 2009. Calibration was carried out in two stages. In the first stage, steady-state simulations were conducted to calibrate the concentrations of TSS in the aeration tank (mixed liquor suspended solids, MLSS) and in the clarifier underflow. In the second stage, $\mathrm{COD}_{\text {tot }}, \mathrm{NO}_{3}$ and $\mathrm{NH}_{4}$ were calibrated for the secondary effluent via dynamic calibration trials. All model calibration trials were carried out by manually fine-tuning the parameters $\mathrm{Y}_{H}, b_{H} K_{O, H}, b_{A}$ and $\eta_{g}$, while setting other parameters to default values [9]. The model was then validated using a different set of data obtained during the period from October 2009 to March 2010. 


\section{Results and discussion}

\subsection{Influent quality}

Table 1 shows the influent characteristics for the period from 2004 to 2007, which on average were as follows: $478 \mathrm{mg} / 1 \mathrm{TSS}, 285 \mathrm{mg} / \mathrm{l} \mathrm{COD}_{\text {tot }}, 187 \mathrm{mg} / \mathrm{l}$ $\mathrm{BOD}_{5}, 26 \mathrm{mg} / \mathrm{l} \mathrm{TKN}$ and $27 \mathrm{mg} / \mathrm{l} \mathrm{TP}$. With the exception of the relatively high TP concentrations, the raw wastewater treated at the Riqqa WWTP in 2004 to 2007, can be characterized as a medium-strength domestic wastewater [10]. The high TP concentrations in the treated raw wastewater might be due to illegal industrial discharge, which is suspected in Kuwait [11]. The high phosphorus concentrations in the plant influent might also be due to the excessive use of phosphorus-rich detergents for domestic cleaning. The exact cause(s) of the high TP concentrations of TP in the Riqqa influent, therefore, need to be investigated further, which is beyond the scope of this study.

Table 1: $\quad$ Characteristics of Riqqa influent from 2004 to 2007.

\begin{tabular}{|l|c|c|c|c|c|}
\hline Year & 2004 & 2005 & 2006 & 2007 & Average \\
\hline TSS mg/l & 191 & 156 & 181 & 218 & 187 \\
\hline $\mathrm{COD}_{\text {tot }} \mathrm{mg} / \mathrm{l}$ & 519 & 393 & 452 & 547 & 478 \\
\hline $\mathrm{BOD}_{5} \mathrm{mg} / \mathrm{l}$ & 280 & 248 & 259 & 354 & 285 \\
\hline $\mathrm{TKN} \mathrm{mg} / \mathrm{l}$ & n.a. & 26.87 & 24.7 & 25.8 & 26 \\
\hline $\mathrm{NO}_{3}-\mathrm{N} \mathrm{mg} / \mathrm{l}$ & n.a. & 4 & 2.8 & 2.2 & 3.0 \\
\hline $\mathrm{TN} \mathrm{mg/l}$ & n.a. & 30 & 7.7 & 28.1 & 29 \\
\hline TP mg/l & n.a. & 21 & n.a. & 31.9 & 27 \\
\hline BOD5/COD & 0.54 & 0.63 & 0.57 & 0.65 & 0.59 \\
\hline
\end{tabular}

Table 1 also shows that raw wastewater treated during 2004-2007 was amenable to biological treatment $\left(\mathrm{BOD}_{5} / \mathrm{COD}=0.59\right)$. The $\mathrm{BOD}_{5}$ to $\mathrm{COD}$ ratio is generally considered to indicate of the wastewater's treatability, as it represents the ratio of easily degradable organic matter to slowly degradable organic matter [12]. Typically the $\mathrm{BOD}_{5} / \mathrm{COD}$ of raw domestic wastewater ranges from 0.3 to $0.8 ; \mathrm{A} \mathrm{BOD}_{5} / \mathrm{COD}$ equal to or greater than 0.5 is usually considered to indicate that the wastewater can easily be treated biologically. Table 2 also shows that the raw wastewater at Riqqa WWTP had sufficient 
nutrients $\left(\mathrm{TKN} / \mathrm{BOD}_{5}=0.09\right.$ and $\left.\mathrm{TP} / \mathrm{BOD}_{5}=0.09\right)$ for biological growth. Typically, the $\mathrm{TKN} / \mathrm{BOD}_{5}$ and $\mathrm{TP} / \mathrm{BOD}_{5}$ ratios are required to be about 0.05 and 0.01 , respectively [13].

\subsection{Secondary effluent}

The quality of secondary effluent of activated sludge at Riqqa from 2004 to 2007 is presented in table 2. Except for the very high COD concentrations $(>100 \mathrm{mg} / \mathrm{l})$ during 2006 and 2007, the quality of the secondary effluent was generally very good and in alignment with expectations for effluents from municipal wastewater systems. Usually, about $30 \mathrm{mg} / \mathrm{l}$ TSS and $30 \mathrm{mg} / \mathrm{l}$ COD concentrations (i.e., $85 \%$ removals of the total TSS and COD) are expected to be achieved in such a system. The high TP concentrations of the effluent are expected, since the system is not designed to remove phosphorus.

Table 2: $\quad$ Quality of the secondary effluent of the Riqqa WWTP from 2004 to 2007 .

\begin{tabular}{|l|c|c|c|c|}
\hline Parameters & 2004 & 2005 & 2006 & 2007 \\
\hline TSS $(\mathrm{mg} / \mathrm{l})$ & 14 & 14 & 11 & 11 \\
\hline $\mathrm{COD}_{\text {tot }}(\mathrm{mg} / \mathrm{l})$ & 32 & 33 & 149 & 125 \\
\hline $\mathrm{BOD}_{5}(\mathrm{mg} / \mathrm{l})$ & 7 & 7 & 6 & 8 \\
\hline $\mathrm{NH}_{3}-\mathrm{N}(\mathrm{mg} / \mathrm{l})$ & n.a. & 0.4 & 0.2 & 0.1 \\
\hline $\mathrm{NO}_{3}-\mathrm{N}(\mathrm{mg} / \mathrm{l})$ & n.a. & 10 & 2.7 & 1.9 \\
\hline $\mathrm{TN}(\mathrm{mg} / \mathrm{l})$ & n.a. & 10 & 1.3 & 2.1 \\
\hline $\mathrm{TP}(\mathrm{mg} / \mathrm{l})$ & n.a. & 12 & 30.4 & 30.1 \\
\hline
\end{tabular}

\subsection{System operational parameters}

Figs. 1 to 4 present the monthly values obtained for the various system operating parameters, together with the lower and upper recommended limits. It is clear from Fig. 1 that most of the time the system was operated close to the minimum recommended HRT (20 h). Fig. 2 shows that, except for 2005, the SRT remained generally within the optimal range of $30-40$ d. However, Fig. 3 indicates that the system was organically overloaded most of the time. Fig. 4 also shows that most of the time, the system was operated at an F/M close to or higher than the recommended upper limit 0.1 . In general, these figures indicate clearly that the plant was operating under inappropriate conditions by means of manual manipulation of the re-circulated activated sludge (RAS) and wasted activated sludge (WAS) streams during 2004 to 2007. Similar findings were also made for the period from March 2009 to March 2010 (figs. 5-8). Figs. 5-6 indicate clearly that the system was working at SRTs and HRTs far below the minimums required. 


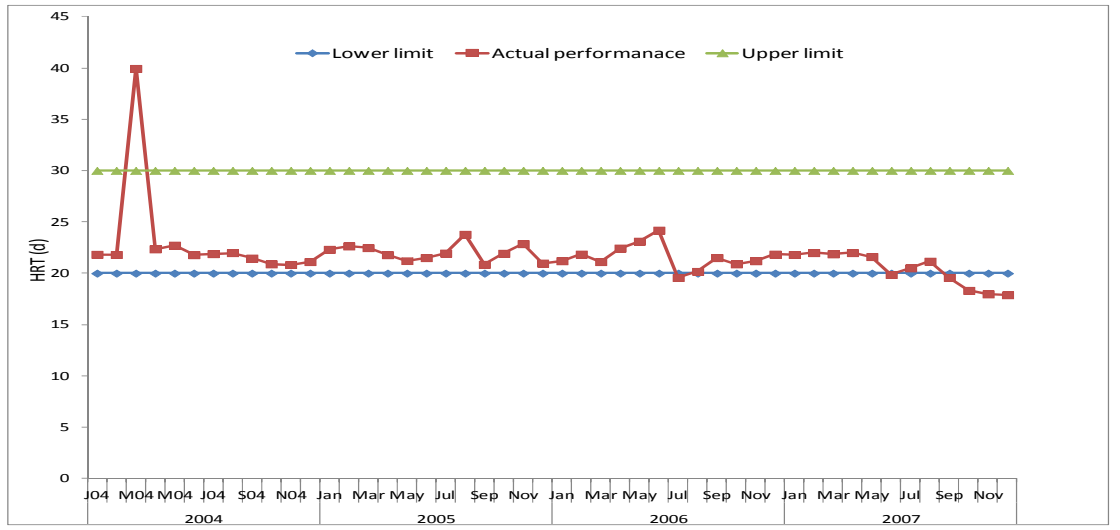

Figure 1: $\quad$ HRT of the Riqqa ASS from 2004 to 2007.

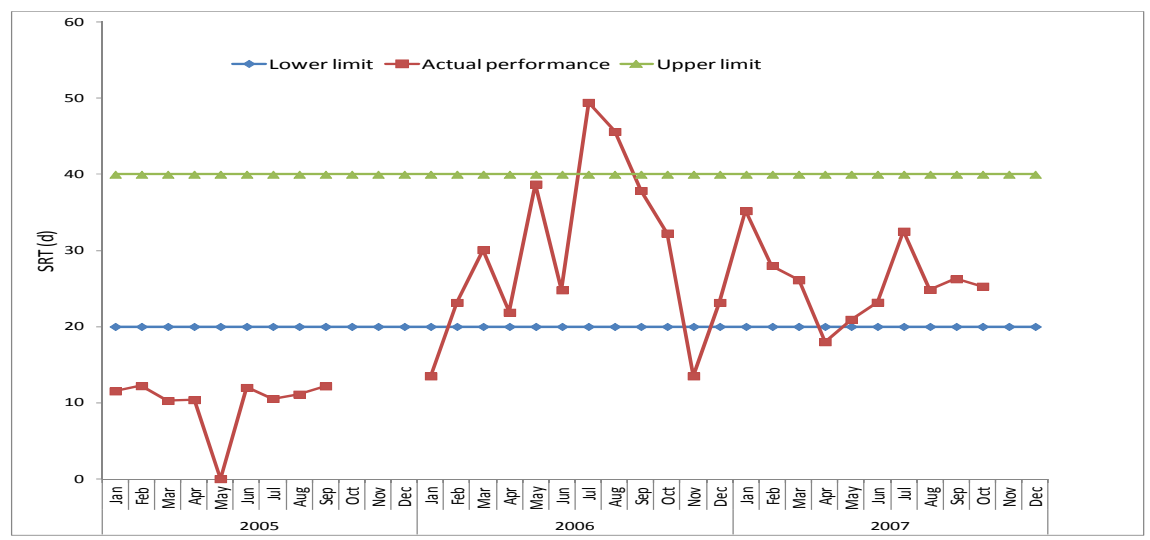

Figure 2: $\quad$ SRT of the Riqqa ASS from 2005 to 2007.

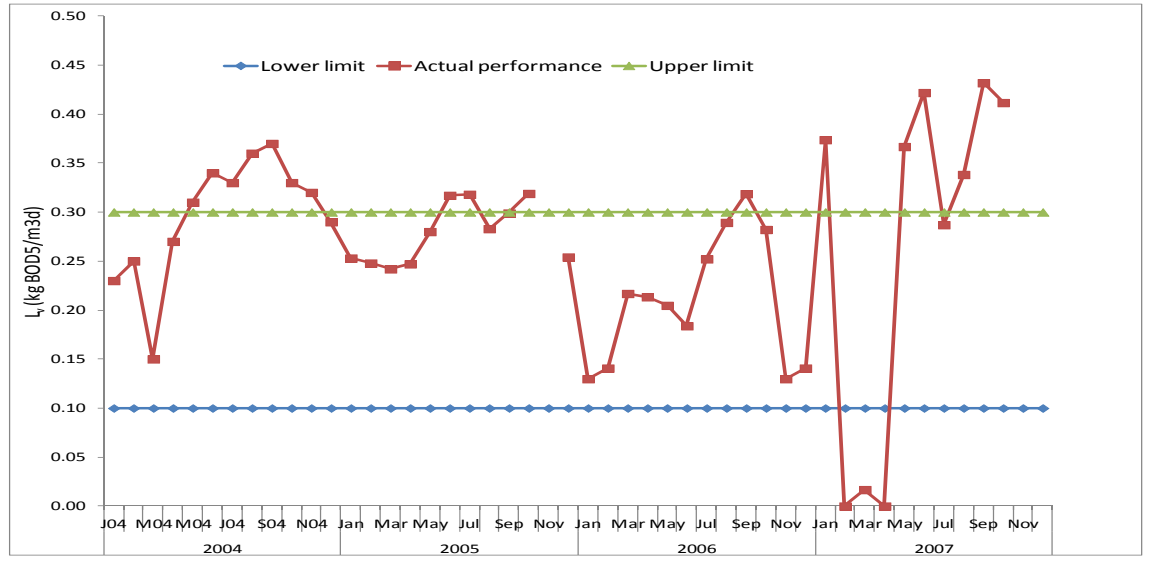

Figure 3: $\quad$ LV in the Riqqa ASS from 2004 to 2007. 


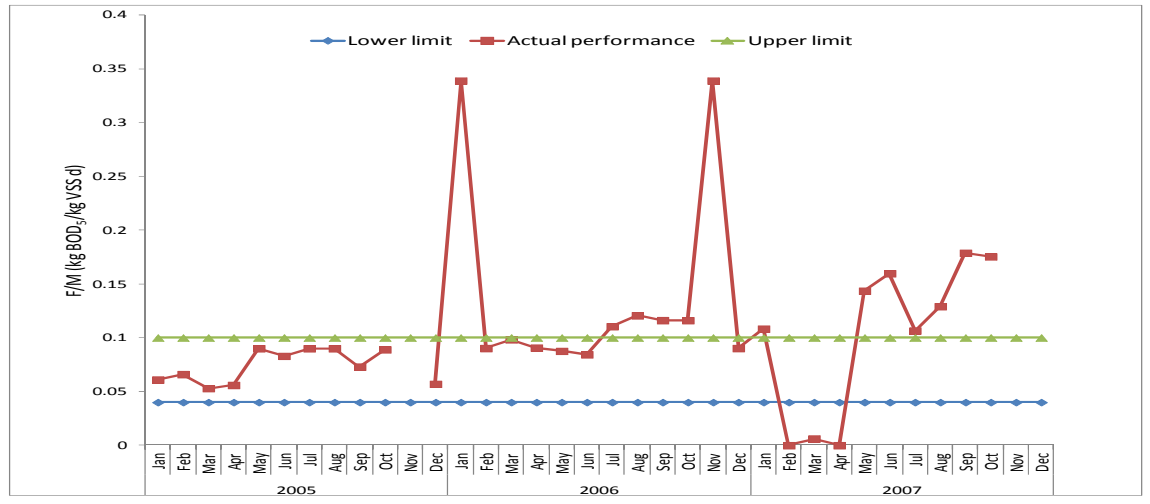

Figure 4: $\quad$ F/M in the Riqqa ASS from 2004 to 2007.

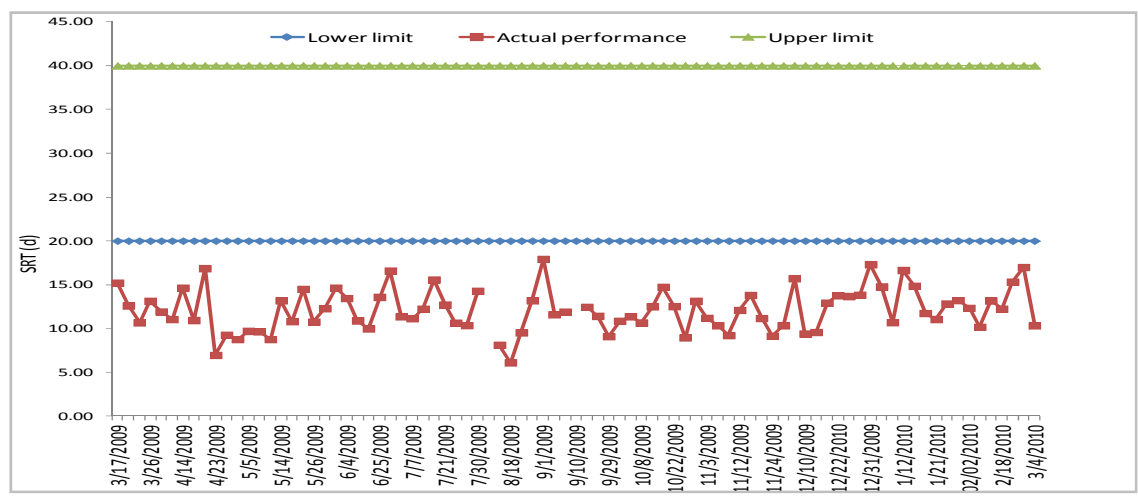

Figure 5: $\quad$ SRT in the Riqqa ASS during 2009 and 2010.

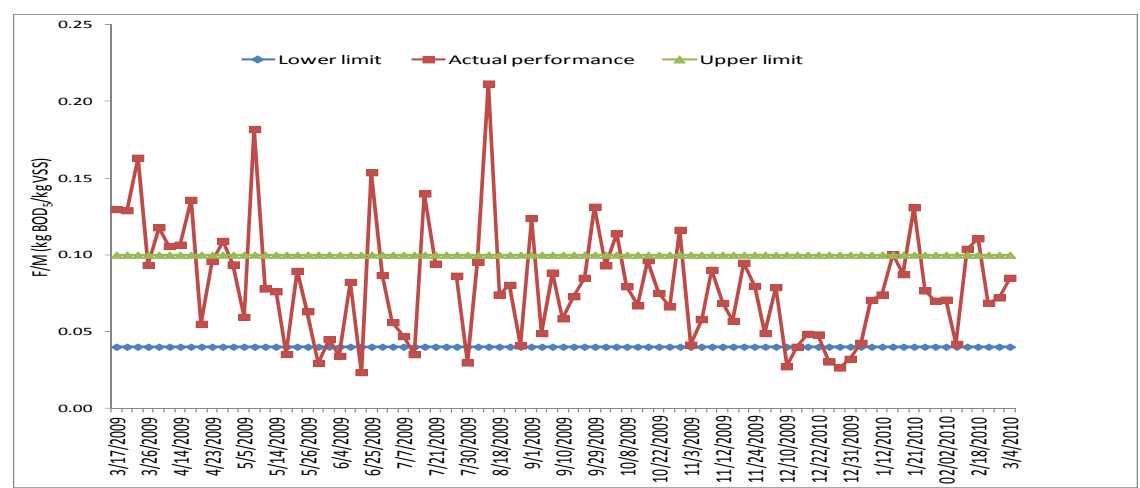

Figure 6: $\quad$ F/M in the Riqqa ASS during 2009 and 2010. 


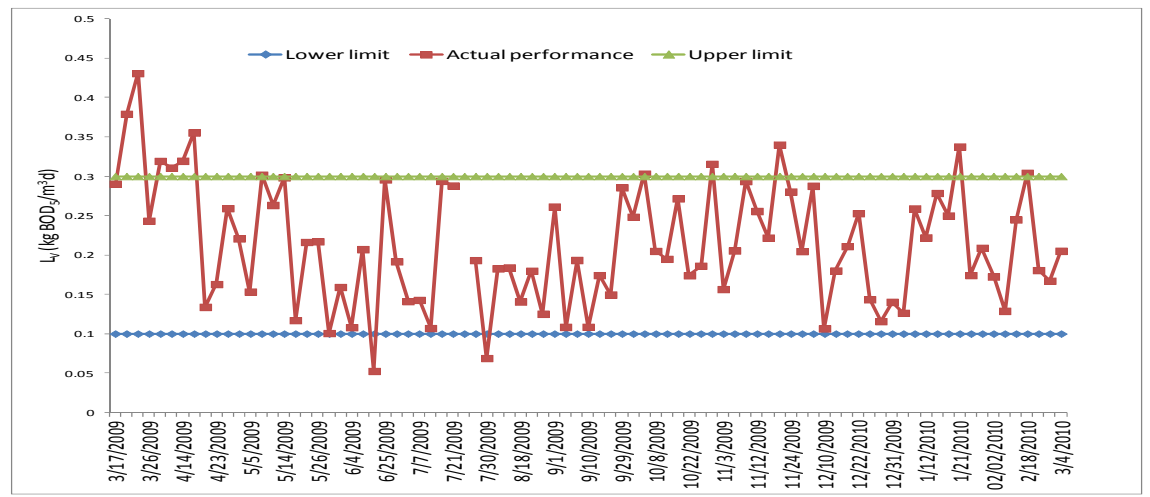

Figure 7: $\quad$ LV in the Riqqa ASS during 2009 and 2010.

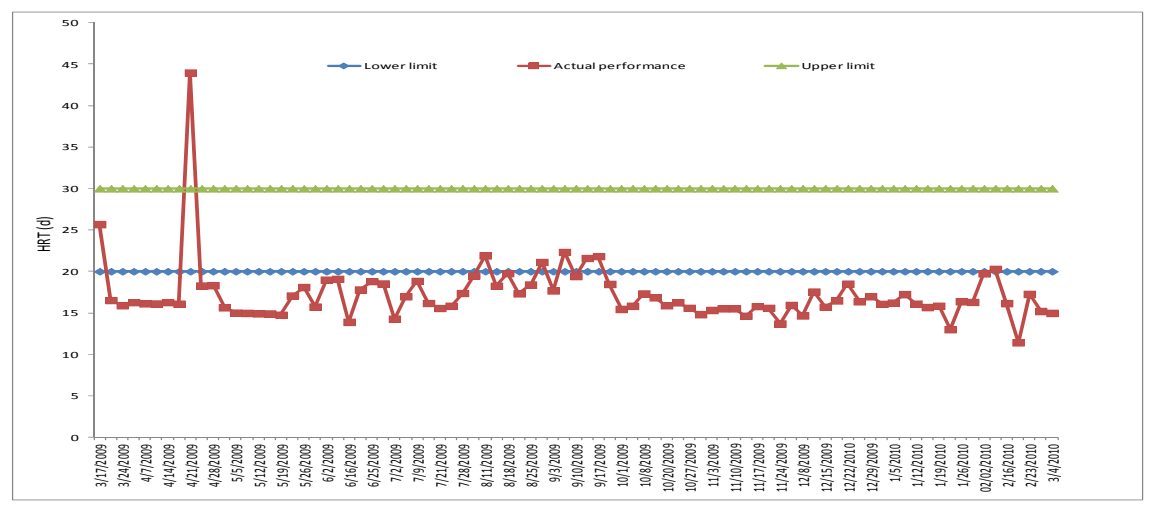

Figure 8: $\quad$ HRT of the Riqqa ASS during 2009 and 2010.

\subsection{System modeling}

In steady-state calibration trials, $\mathrm{X}_{\mathrm{I}}$ was found to be about $45 \%$ of $\mathrm{COD}_{\text {tot }}, b_{H}$ was found to be $0.10 \mathrm{~d}^{-1}$ and $b_{A}$ was found to be $0.05 \mathrm{~d}^{-1}$. These values compare well with the values reported in the literature for domestic wastewater [11, 14]. In dynamic calibration, the values of the parameters $Y_{H}, K_{O H}, K_{S}$ and $\eta_{g}$ were found to be $0.67,0.5$, and 30 , respectively, values that are also within the ranges reported in literature for domestic wastewater [11, 15]. Figs. 9 and 10 present some of the results obtained from model validation, demonstrating that the model is generally capable of predicting the concentrations of carbon and nitrogen constituents in the secondary effluent, i.e. the model can be used to control the system and to predict the system's future performance. 


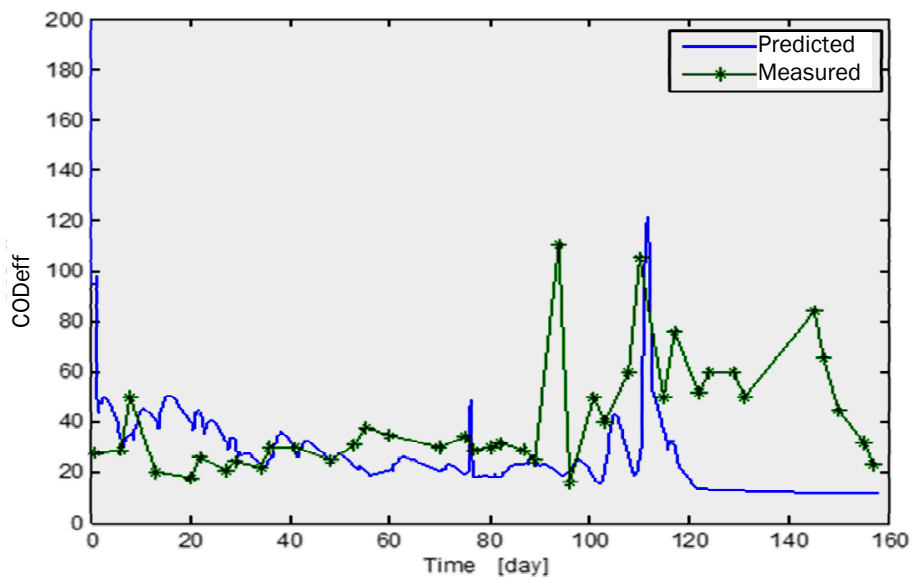

Figure 9: Validation of $\mathrm{COD}_{\text {tot }}$ in the secondary effluent.

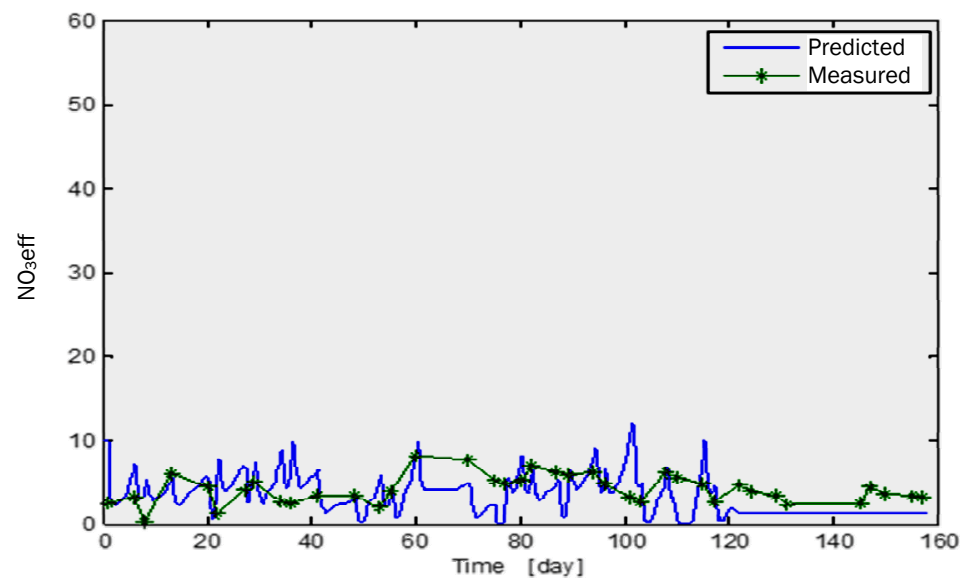

Figure 10: Validation of $\mathrm{NO}_{3}$ in the secondary effluent.

\section{Conclusions and recommendations}

- Performance evaluations have indicated that the unstable performance of the Riqqa ASS can be attributed to a failure to operate the system within optimal ranges and with high fluctuations in influent quality, especially with regard to particulate COD, probably due to illegal discharges of septage or industrial wastes. 
- Automatic wastewater flow controllers should be installed in the RAS and WAS streams to automatically and precisely control the amount of biomass being wasted or recycled into the system.

- Based on ASM1, a mathematical model has been developed for the Riqqa ASS, which can be utilized to control and optimize the system's performance.

\section{Acknowledgements}

The authors are grateful for the funding obtained from the Kuwait Institute for Scientific Research (KISR) and the Kuwait Foundation for the Advancement of Sciences (KFAS) for the study.

\section{References}

[1] MP, Edition 39, Statistics and IT Sector, Annual Statistical Abstract, Ministry of Planning, Kuwait, 2002.

[2] Al-Shammari, S. \& Shahalam, A.M., Water demand and wastewater management in Kuwait. Proc. of the $7^{\text {th }}$ Gulf Water Conf., Water in the GCC - Towards an Integrated Management, WASTA, Bahrain, pp. $701-$ 709, 2005.

[3] Shahalam, A.M., Al-Shammari, S., Abusam, A. \& and Al-Naser, H., Present and future wastewater quantities and reuse demand in Kuwait, Kuwait Institute for Scientific Research Report No. KISR 8954, Kuwait, 2007.

[4] Hamoda, M.F., AL-Ghusain, I. \& AL-Mutairi, N.Z., Sand filtration of wastewater for tertiary treatment and reuse, Desalination 164 (1 - 3), pp. $203-211,2004$.

[5] MPW, Kuwait Sanitary Master Plan, Prepared by Parsons EngineeringScience, Inc. and Gulf Consult, Sanitary Engineering Department, for Ministry of Public Works, Kuwait, 2002.

[6] APHA, Standard methods for examination of water and wastewater, $20^{\text {th }}$ ed., American Public Health Association, Washington D.C., US, 2005.

[7] Takacs, I., Patry, G.G. \& Nolasco, D., A dynamic model of the clarification-thickening process. Water Research, 25 (10), pp. 1263-1271, 1991.

[8] Davis J.T., Turbulence Phenomena: An Introduction to the Eddy Transfer of Momentum, Mass, and Heat, Particularly at Interfaces, New York, Academic Press, 1972.

[9] Abusam, A.; Keesman, K.J., van. Straten, G., Spanjers, H. \& Meinema, K., Sensitivity analysis in oxidation ditch modeling - the effect of variations in stoichiometric, kinetic and operating parameters on the performance indices. Journal of Chemical Technology and Biotechnology, 76 (4), pp. 430 - 438, 2001.

[10] MetCalf \& Eddy, Wastewater Engineering Treatment, Disposal, Reuse, $3^{\text {rd }}$ ed. New York, McGraw-Hill Publishing Company, Ltd., 2003 
[11] Orhon, D. \& Artan, N., Modeling Activated Sludge Systems, US, Technomic Publishing Co., Inc., 1994.

[12] Ghobrial, F., Lionel, M., Patel, B. \& Awad, A., Assessment of raw sewage and treated effluents characteristics in Kuwait, Kuwait Institute for Scientific Research, Report No. KISR 2468, Kuwait, 1987.

[13] Orhon, D., Ates, E., Sozen, S. \& Cokgor, E. U., Characterization and COD fractionation of domestic wastewaters, Environmental Pollution 95 (2), pp. 191-204, 1997.

[14] Hammer, M.J. \&. Jr. Hammer, Jr., M.J., Water and Wastewater Technology, $3^{\text {rd }}$ ed., US, Prentice Hall, 1996.

[15] Henze, M., Gujer, W., Mino, T., Matsuo, T., Wentzel, M.C.M. \& Marias, G. V. R., Activated Sludge Model No. 2, IAWQ, Scientific and Technical Report No. 3, London, UK, 1995.

[16] Davis, M.L. \& Cornwell, D. A., Introduction to Environmental Engineering, ${ }^{\text {rd }}$ ed., McGraw-Hill, Singapore, 1998. 